Tạp chi Khoa học và Công nghệ, Số 30, 2017

\title{
IDENTIFYING CRITICAL SUCCESS FACTORS FOR CONSTRUCTION PARTNERING IN VIETNAM
}

\author{
DANG NGOC CHAU ${ }^{1}$, LE HOAI LONG ${ }^{2}$ \\ ${ }^{1}$ Industrial University of Ho Chi Minh City, \\ ${ }^{2}$ Ho Chi Minh City University of Technology - Vietnam National University; \\ dangngocchau@iuh.edu.vn,lehoailong@hcmut.edu.vn
}

\begin{abstract}
Partnering has been applied in the Vietnamese construction industry for several recent years, due to many new challenges emanating from the global integration and economic booming. This paper focuses on critical success factors (CSFs) for partnering in the Vietnamese construction industry. Using mean score method, this paper identifies six key CSFs for partnering in Vietnamese construction, including financial security, commitment from top management, mutual trust between parties, adequate resources, effective communication, and clear understanding about scope and objectives. Using factor analysis technique, eight underlying components for partnering in Vietnamese construction are extracted, including dedication, readiness, coordination, teamwork, sufficiency, leading, balance, and clearness. The findings could provide construction practitioners with useful information for deploying partnering in the Vietnamese construction industry and, hence, increase the chance of partnering success.
\end{abstract}

Keywords. construction, critical success factors, partnering, Vietnam.

\section{INTRODUCTION}

Construction parties have faced some inherent difficulties of construction projects, such as disputes. A framework for mutual objectives among parties, which could reach an agreed dispute resolution procedure and encourage principles of continuous improvement (Naoum [18]), needs to be established. Mutual trust among parties, which could encourage them to maximize their contributions to project success, also needs to be created. Partnering might be one of the most innovative developments in delivering a project efficiently and reducing construction disputes. Partnering provides a sound basis for achieving a win-win situation and implementing synergistic teamwork (Chen and Chen [5]). Thus, understanding of how to apply partnering successfully is useful to construction parties.

In Vietnam, partnering is a rather new concept. Partnering implementation has encountered many difficulties, despite many partnering advantages such as diverse nature, professional knowledge, and organizational culture (Le-Hoai et al. [15]). In the Vietnamese construction industry, although problematic issues for partnering implementation were investigated (Le-Hoai et al. [15]), many practitioners still have little experience with partnering practices. Undoutedly, a better understanding of how to improve partnering practices is necessary. Strategies to enhance partnering performance could be established through identifying critical success factors (CSFs) (Toor and Ogunlana [24]). Construction companies could devise better strategies which focus on improving resource use, project delivery processes and productivity, when they understand, manage and exploit underlying differences in the perception of CSFs (Toor and Ogunlana [24]; Phua [21]). Thus, this paper aims to identify CSFs for partnering practices in the Vietnamese construction industry.

\section{LITERATURE REVIEW}

Many studies have focused on identifying CSFs for partnering in construction. Black et al. [2] analyzed CSFs and benefits of partnering in construction. Using a UK-wide postal questionnaire survey, opinions of different types of organization (e.g. consultants, contractors, and clients) were assessed in relation to CSFs and benefits of partnering. Cheng et al. [7] established CSFs for construction partnering. Based on a review of the partnering literature within the management discipline, a partnering framework was developed to identify CSFs for construction parties that implemented partnering arrangements. Chan et al. [3] explored CSFs for partnering in construction projects. This study presented a review of the 
development of the partnering concept in general and identified CSFs for partnering projects from Hong Kong perspective in particular. Lehtonen [16] defined attributes of partnering relations and identified key factors which could help a relationship to succeed. Chen and Chen [5] attempted to distinguish CSFs based on degrees of importance in relation to success. Chen et al. [6] assessed critical factors as certain requirements that had to be met for partnering to be successful.

Several other studies have attempted to model the performance of construction partnering. Larson [14] studied the relationship between specific partnering-related activities and project success using 291 construction projects. Cheng and Li [8] developed a conceptual model of construction partnering. The model explored the relationship between two types of partnering (project and strategic) by studying key factors that could affect partnering process stages. Cheng and Li [9] examined a customized model of construction partnering in order to highlight the relationships between CSFs and individual partnering process stages. Cheng et al. [10] presented a long-term commitment model which could support the long existing change process of a strategic alliance in construction. This model embraced components which helped to stimulate the level of employee and management commitment in order to satisfy stakeholders. Based on a case study of six selected projects, Chan et al. [4] developed a best practice partnering framework for Hong Kong context. Tang et al. [23] conducted a study to develop and test a partnering model that could reveal the relationships between CSFs of partnering and demonstrate their importance to construction.

The literature review shows that identifying CSFs of partnering in construction is necessary. However, various potential factors could contribute to partnering success, which changes not only from country to country but also from project to project. So far, the underlying relationships of CSFs for partnering practices in the Vietnamese construction industry have not been explored. Thus, this paper attempts to fill this gap.

\section{RESEARCH METHODOLOGY}

A list of potential CSFs was identified through literature review, cases analysis in newspapers, and discussions in professional fora. A group of six experts, which had at least twelve years of experience in construction, was invited to review the appropriateness and sufficiency of the listed potential CSFs. They had much experience not only in construction projects but also in partnering projects. Their valuable comments were used to revise the list of potential CSFs. Then, a preliminary questionnaire was designed and sent to six aforementioned experts for review. The pilot test was completed when the structure of the questionnaire and the included CSFs were generally agreed by most experts. The final questionnaire was finalized with $28 \mathrm{CSF}$.

A list of respondents was identified through construction companies' web-pages, construction companies' charters, project case analyses, professional fora, and personal relationships. Respondents were requested to rate $28 \mathrm{CSFs}$ in construction projects, in which they were directly involved, on a fivepoint Likert scale from $1=$ "insignificant" to $5=$ "very highly significant". Although respondents were pre-specified to be involved in partnering projects, they were also asked whether they participated in any partnering project to ensure the reliability of the collected data. Returned questionnaires with answer "no experience" were discarded.

Hand-delivery and e-mailing methods were used to conduct the survey. A total of 79 valid returned questionnaires accounted for a response rate of about $24 \%$ were used for analyses. Data processing was performed using the SPSS software. The reliability test yielded a Cronbach's alpha coefficient of internal consistency value of $0.0 .887(>0.80)$, which is considered to be reliable.

Out of 79 valid returned questionnaires, $20.3 \%, 20.3 \%$, and $59.5 \%$ questionnaires were colleted from clients, consultants, and contractors, respectively. About position, $12.7 \%, 49.4 \%, 32.9 \%$, and $5.1 \%$ respondents were top managers, functional managers, project team members, and partnering facilitators, respectively. In terms of experience, $15.2 \%, 36.7 \%, 40.5 \%$, and $7.6 \%$ respondents had less than $5,5-10$, $10-15$, and more than 15 years of experience, respectively. Regarding origin of organization, $32.9 \%$ and $67.1 \%$ responses were from foreign and Vietnamese sectors. 


\section{RANKING OF CSFS FOR CONSTRUCTION PARTNERING IN VIETNAM}

Mean score method is used to calculate the mean values for 28 CSFs of partnering in the Vietnamese construction industry. As the data are collected from different sectors (i.e. foreign sector and Vietnamese sector), $t$ test is employed to check whether the mean values of each CSF rated by the two aforementioned groups are different. The results of $t$ test indicate that there is no significant difference in the ratings of the two aforementioned groups at the 0.05 level. Thus, the collected data could be used as a whole for further analyses.

Table 1 presents the results of mean and ranking for $28 \mathrm{CSFs}$ for construction partnering in Vietnam. In general, all $28 \mathrm{CSF}$ have the mean values larger than 3.0, of which several CSFs have mean values larger than 4.0 .

Table 1. Ranking of CSFs for construction partnering.

\begin{tabular}{|c|c|c|c|c|}
\hline Code & CSFs for construction partnering & Mean & Standard deviation & Rank \\
\hline F1 & Mutual trust between parties & 4.27 & 0.73 & 3 \\
\hline $\mathrm{F} 2$ & Effective communication & 4.13 & 0.82 & 5 \\
\hline F3 & Adequate resources & 4.23 & 0.99 & 4 \\
\hline F4 & Long-term commitment & 3.87 & 0.79 & 8 \\
\hline F5 & Commitment from top management & 4.32 & 0.79 & 2 \\
\hline F6 & Clear understanding about scope and objectives & 4.06 & 0.84 & 6 \\
\hline F7 & Early implementation of partnering process & 3.34 & 1.05 & 26 \\
\hline F8 & Commitment to continuous improvement & 3.56 & 0.94 & 22 \\
\hline F9 & Acting consistent with objectives & 3.75 & 0.78 & 15 \\
\hline F10 & Dedicated team & 3.84 & 0.94 & 14 \\
\hline F11 & Flexibility to change & 3.71 & 0.83 & 18 \\
\hline F12 & Commitment to quality & 3.86 & 0.97 & 10 \\
\hline F13 & Total cost perspective & 3.35 & 1.09 & 25 \\
\hline F14 & Good cultural fit & 3.01 & 0.91 & 28 \\
\hline F15 & Company's wide acceptance about partnering & 3.28 & 0.93 & 27 \\
\hline F16 & Technical expertise & 3.85 & 0.89 & 11 \\
\hline F17 & Financial security & 4.49 & 0.68 & 1 \\
\hline F18 & Questioning attitude about assumptions & 3.62 & 0.9 & 21 \\
\hline F19 & Empowerment of stakeholders & 3.87 & 0.93 & 8 \\
\hline F20 & Creativity of partnering team & 3.42 & 0.93 & 24 \\
\hline F21 & Equity & 3.85 & 0.85 & 11 \\
\hline F22 & Mutual vision, goals/objectives & 3.70 & 0.95 & 19 \\
\hline F23 & Effective conflict resolution process & 3.89 & 0.82 & 7 \\
\hline F24 & Educated and trained personnel for partnering & 3.68 & 0.79 & 20 \\
\hline F25 & Effective coordination & 3.73 & 0.75 & 16 \\
\hline F26 & Adequate partnering team building & 3.72 & 1.01 & 17 \\
\hline F27 & Partnering experience & 3.52 & 0.89 & 23 \\
\hline F28 & Joint problem solving & 3.85 & 0.74 & 11 \\
\hline
\end{tabular}

Several CSFs, which have the mean values larger than 4.0, are considered as important for partnering practices (Table 1). Financial security (F17), which has rank 1, is considered as the most important to successful partnering implementation in Vietnam. Finance is a big concern of construction participants in the Vietnamese construction market. In a partnership, to run construction projects smoothly, finance burden should be shared among construction partners. When entering into a new construction market, foreign parties usually find local partners to share financial-related risks. Commitment from top management (F5) has rank 2 and, therefore, is considered as a requirement for partnering success. Commitments could embody the full support and commitment of top management in formulating the strategy and direction of business activities (Cheng and Li [8]). Other four CSFs which are also found to be important to construction partnering in Vietnam are mutual trust between parties ( $F 1$, rank 3), adequate resources (F3, rank 4), effective communication (F2, rank 5), and clear understanding about scope and objectives (F6, rank 6). It can be seen that these CSFs could be vital to partnering practices in the 
Vietnamese construction industry and, therefore, construction parties should perform them well to improve partnering practices.

Other CSFs may be less important to partnering success. However, construction parties should not ignore them, as their mean values are also high (larger than 3.0). On the other hand, it is very difficult for construction parties, which join partnering projects, to perform a number of CSFs well. Thus, to provide a better understanding of CSFs for construction partnering in Vietnam, factor analysis will be employed.

\section{FACTOR ANALYSIS}

\subsection{Results}

Table 2. Results of factor analysis.

\begin{tabular}{|c|c|c|c|c|}
\hline Code & Components/ CSFs for construction partnering & Loading & Eigenvalue & Variance explained \\
\hline$C 1$ & Dedication & & 7.97 & 28.45 \\
\hline F20 & Creativity of partnering team & 0.752 & & \\
\hline F9 & Acting consistent with objectives & 0.734 & & \\
\hline F11 & Flexibility to change & 0.732 & & \\
\hline F8 & Commitment to continuous improvement & 0.673 & & \\
\hline F13 & Total cost perspective & 0.576 & & \\
\hline F10 & Dedicated team & 0.556 & & \\
\hline F7 & Early implementation of partnering process & 0.507 & & \\
\hline$C 2$ & Readiness & & 2.78 & 9.93 \\
\hline F15 & Company's wide acceptance about partnering & 0.847 & & \\
\hline F16 & Technical expertise & 0.699 & & \\
\hline F14 & Good cultural fit & 0.618 & & \\
\hline $\mathrm{F} 2$ & Effective communication & 0.544 & & \\
\hline F1 & Mutual trust between parties & 0.528 & & \\
\hline C3 & Coordination & & 2.16 & 7.72 \\
\hline F25 & Effective coordination & 0.715 & & \\
\hline F24 & Educated and trained personnel for partnering & 0.637 & & \\
\hline F18 & Questioning attitude about assumptions & 0.637 & & \\
\hline C4 & Teamwork & & 1.99 & 7.12 \\
\hline F28 & Joint problem solving & 0.814 & & \\
\hline F27 & Partnering experience & 0.735 & & \\
\hline $\mathrm{F} 22$ & Mutual vision, goals/objectives & 0.415 & & \\
\hline C5 & Sufficiency & & 1.53 & 5.46 \\
\hline F3 & Adequate resources & 0.753 & & \\
\hline F23 & Effective conflict resolution process & 0.750 & & \\
\hline C6 & Leading & & 1.35 & 4.80 \\
\hline F17 & Financial security & 0.658 & & \\
\hline F5 & Commitment from top management & 0.650 & & \\
\hline F21 & Equity & 0.581 & & \\
\hline F4 & Long-term commitment & 0.510 & & \\
\hline$C 7$ & Balance & & 1.19 & 4.24 \\
\hline F26 & Adequate partnering team building & 0.806 & & \\
\hline F12 & Commitment to quality & 0.645 & & \\
\hline F19 & Empowerment of stakeholders & 0.574 & & \\
\hline$C 8$ & Clearness & & 1.06 & 3.77 \\
\hline F6 & $\begin{array}{l}\text { Clear understanding about scope and objectives } \\
\text { Total variance explained }\end{array}$ & 0.844 & & 71.50 \\
\hline
\end{tabular}

Factor analysis is employed to identify the latent relationships of CSFs for partnering in the Vietnamese construction industry. Several tests for applying factor analysis are conducted (Hair et al. [13]). Kaiser-Meyer-Olkin measure of sampling adequacy is satisfactory with the value of 0.685 . Bartlett's test of sphericity is significant at 0.000 with Chi-square value of $1,258.335$, indicating that the correlation matrix is not an identity matrix. Communality values of all 28 CSFs are higher than 0.5. All tests indicate that factor analysis is applicable for 28 CSFs using the collected data. 
Latent root criterion (i.e. eigenvalue greater than 1) and varimax rotation method are used to extract the underlying principle components. In total, 8 components, having eigenvalues greater than 1 and explaining $71.5 \%$ of variance, are extracted, including dedication $(\mathrm{C} 1)$, readiness $(\mathrm{C} 2)$, coordination $(\mathrm{C} 3)$, teamwork (C4), sufficiency (C5), leading (C6), balance (C7), and clearness (C8) (Table 2). It is suggested that parties in the Vietnamese construction industry should focus on these components to improve partnering practices and, therefore, ensure partnering success in construction projects.

\subsection{Discussions}

Dedication (C1) explains a variance of $28.45 \%$. It comprises of $7 \mathrm{CSF}$, including creativity of partnering team (F20), acting consistent with objectives (F9), flexibility to change (F11), commitment to continuous improvement (F8), total cost perspective (F13), dedicated team (F10), and early implementation of partnering process (F7). Construction projects are dynamic and intricate in nature. Implementation of construction projects needs both artistic and scientific manners. Creativity and flexibility are important to partnering in construction projects. Creativity shows under various forms, such as thinking of novel ideas or liking to use advanced techniques (Cheng et al. [7]). Nevertheless, all actions must be consistent with specified objectives of partnering projects. Parties should ensure that they have synchronous goals and review accomplishments in terms of original goals (Chen and Chen [5]). Furthermore, commitment to continuous improvement, dedicated team, early implementation of partnering process are necessary to partnering practices and partnering success in construction projects.

Readiness (C2) is vital to start and maintain a collaborative relationship. Readiness, which explains a variance of 9.93\%, includes company's wide acceptance about partnering (F15), technical expertise (F16), good cultural fit (F14), effective communication (F2), and mutual trust between parties (F1). An organization which is ready for partnering can promote its success. Partners in construction, if ready for partnering, should have wide acceptance of organization and good preparation of technical expertise and cultural issues. Partners must set up effective communication systems and develop mutual trusts in partnerships to reach mutual goals.

Coordination (C3), which explains $7.72 \%$ of variance, is a widely recognized important factor for partnering success. Coordination consists of effective coordination (F25), questioning attitude about assumptions (F18), and educated and trained personnel for partnering (F24). Achievement of effective coordination could obtain the stability in an uncertain environment, which can be attained by an increase in contact points between parties and sharing of information (Bayramoglu [1]). Parties should have questioning attitudes to reduce coordination problems, such as misunderstanding or misinterpretation. Personnel should be educated or trained about partnering before and during partnering implementation. Out of regular skills for working in partnering environment, it should focus on training about coordination. When coordination mechanism in partnering is well established, it could encourage all members to act consistently with objectives.

Teamwork (C4) is prominent as a critical component relating to partnering success in the Vietnamese construction industry, but in fact, teamwork is not a habitual conception. Teamwork, which explains $7.12 \%$ of variance, includes joint problem solving (F28), partnering experience (F27), and mutual vision, goals/objectives (F22). Joint problem solving is a productive technique of the teamwork style. Joint problem solving is a collective decision made by partnering teams to create alternatives for problematic issues (Cheng and Li [8]). Partnering experience helps to speed up the partnering progress based on the knowledge, skills, tools, and practices accumulated through past events. Experience matters consume much time for training and perceiving. Mutual trust and shared mutual vision or goals within a team are crucial subjects for team members to work together.

Sufficiency (C5), which explains $5.46 \%$ of variance, could be described by adequate resources (F3) and effective conflict resolution process (F23). Since a construction project requires various skills and technologies, each participating party must supply required resources to share with others, which are enough to support a successful partnering (Cheng and Li [8]). Adequate resources could facilitate problem solving by improving the capacity of organizations to execute innovative ideas (Crowley and Karim [12]). Conflict exists in all entities where mutually interactive activities are present, especially in a partnership. If managed properly, conflict contributes to success of partnership because it could lead to creative solutions, which enhance the ability that partners to work together in the future (Crowley and Karim [12]). 
Leading (C6), which explains $4.8 \%$ of variance, consists of financial security (F17), commitment from top management (F5), equity (F21), and long-term commitment (F4). Financial security is a strategic goal specified by top management to join a partnership. Finance is one of inherent barriers of Vietnamese firms while competition in the Vietnamese market greatly depends on the capability of capital supplies. Assuring good finance is one of incentives of partnering implementation in the Vietnamese construction industry. Equity is also a CSF for launching a partnering. Equity will guarantee that all stakeholders' interests are considered when creating and reviewing mutual goals. When financial security and equity can be obtained from partnering, it will enhance commitments from top management. Full support and commitment of senior managers in formulating strategies and directions of business activities represent the commitment from top management (Cheng and Li [8]). Support from senior managers is always a pre-requisite for successful partnering (Slater [22]). As a consequence of top management commitment, long-term commitment of parties in partnerships will be promoted. Commitment of one party to maintain current partnering relationships with other parties based on some positive aspects (Cheng and Li [8]). In Vietnam, sustaining good relationships with key partners could lead to many incentives, such as increasing bidding advantages or increasing market share.

Balance (C7), which explains $4.24 \%$ of variance, includes adequate partnering team building (F26), commitment to quality (F12), and empowerment of stakeholders (F19). A partnering team should consist of members from all involved parties, whose representatives should be key executives and possess authorities to act on behalf of organizations (Loraine [17]). The consistency and appropriateness of teams' decisions are high and the implementation process of these decisions could be facilitated. In addition, stakeholders must be empowered equally with requisite decision making authorities for efficient problems solving (Ng et al. [19]). Equal empowerments could promote stakeholders' commitment to partnering projects. Moreover, it is necessary to reach a balance between quality and economic constraints. All parties in partnerships present continuous improvement to achieve effectiveness of work, guarantee of quality, and customer satisfaction (Chen and Chen [5]).

Clearness (C8) is significant to partnering projects. Clearness, which is described by clear understanding about scope and objectives (F6), explains 3.77\% of variance. Ambiguous scope and objectives statements of parties could raise adversarial relationships in partnerships. On the other hand, with clear understanding of scope and objectives, parties can work together to make plans become a reality (Crane et al. [11]). Clear project scope and objectives play a key role in achieving a successful construction project in Vietnam (Nguyen et al. [20]).

\section{CONCLUSIONS}

This paper provided a list of 28 CSFs with the mean values and rankings for partnering in the Vietnamese construction industry. Six CSFs were considered as important for partnering practices, including financial security, commitment from top management, mutual trust between parties, adequate resources, effective communication, and clear understanding about scope and objectives. Thus, parties that participate in partnering projects should focus more on these CSFs to improve partnering performance effectively.

This paper also identified eight underlying components extracted from 28 CSFs, including dedication, readiness, coordination, teamwork, sufficiency, leading, balance, and clearness. As these underlying components could generally characterize for partnering in the Vietnamese construction industry, construction parties should pay attention to them to improve their capacity of partnering implementation and, hence, ensure partnering success.

\section{REFERENCES}

[1] S. Bayramoglu, Partnering in construction: improvement through integration and collaboration, Leadership and Management in Engineering, vol. 1, no. 3, pp. 39-43, 2001.

[2] C. Black, A. Akintoye, and E. Fitzgerald, An analysis of success factors and benefits of partnering in construction, International Journal of Project Management, vol. 18, no. 6, pp. 423-434, 2000. 
[3] A. Chan, D. Chan, Y. Chiang, B. Tang, E. Chan, and K. Ho, Exploring critical success factors for partnering in construction projects, Journal of Construction Engineering and Management, vol. 130, no. 2, pp. 188-198, 2004.

[4] A.P.C. Chan, D.W.M. Chan, L.C.N. Fan, P.T.I. Lam, and J.F.Y. Yeung, Partnering for construction excellence - A reality or myth?, Building and Environment, vol. 41, no. 12, pp. 1924-1933, 2006.

[5] W.T. Chen and T.T. Chen, Critical success factors for construction partnering in Taiwan, International journal of Project Management, vol. 25, no. 5, pp. 475-484, 2007.

[6] W.T. Chen, Y.H. Huang, C.L. Lin, and L. Mortis, A framework of critical factors for construction partnerships in Taiwan, in Proceedings of IEEE International Conference on Communications, 2008, pp. 5553-5557.

[7] E.W.L. Cheng, H. Li, and P.E.D. Love, Establishment of critical success factors for construction partnering, Journal of Management in Engineering, vol. 16, no. 2, pp. 84-92, 2000.

[8] E.W.L. Cheng and H. Li, Development of a conceptual model of construction partnering, Engineering, Construction and Architectural Management, vol. 8, no. 4, pp. 292-303, 2001.

[9] E. Cheng and H. Li, Construction partnering process and associated critical success factors: quantitative investigation, Journal of Management in Engineering, vol. 18, no. 4, pp. 194-202, 2002.

[10] E.W. Cheng, H. Li, P.E. Love, and Z. Irani, Strategic alliances: a model for establishing long-term commitment to inter-organizational relations in construction, Building and Environment, vol. 39, no. 4, pp. 459-468, 2004.

[11] T.G. Crane, J.P. Felder, P.J. Thompson, M.G. Thompson, and S.R. Sanders, Partnering process model, Journal of Management in Engineering, vol. 13, no. 3, pp. 57-63, 1997.

[12] L.G. Crowley and M.A. Karim, Conceptual model of partnering, Journal of Management in Engineering, vol. 11, no. 5, pp. 33-39, 1995.

[13] J.F. Hair, W.C. Black, B.J. Babin, and R.E. Anderson, Multivariate data analysis, Prentice Hall, 2009.

[14] E. Larson, Partnering on construction projects: a study of the relationship between partnering activities and project success, IEEE Transaction on Engineering and Management, vol. 44, no. 2, pp. 188-195, 1997.

[15] L. Le-Hoai, Y.D. Lee, and J.J. Son, Partnering in construction: investigation of problematic issues for implementation in Vietnam, KSCE Journal of Civil Engineering, vol. 14, no. 5, pp. 731-741, 2010.

[16] T. Lehtonen, Attributes and success factors of partnering relations - A theoretical framework for facility services, Nordic Journal of Surveying and Real Estate Research, vol. 2, pp. 31-46, 2004.

[17] R.K. Loraine, Project specific partnering, Engineering, Construction and Architectural Management, vol. 1, no. 1, pp. 5-16, 1994.

[18] S. Naoum, An overview into the concept of partnering, International Journal of Project Management, vol. 21, no. 1 , pp. 71-76, 2003.

[19] S.T. Ng, T.M. Rose, M. Mak, and S.E. Chen, Problematic issues associated with project partnering - the contractor perspective, International Journal of Project Management, vol. 20, no. 6, pp. 437-449, 2002.

[20] L.D. Nguyen, S.O. Ogunlana, and D.T.X. Lan, A study on project success factors in large construction projects in Vietnam, Engineering, Construction and Architectural Management, vol. 11, no. 6, pp. 404-413, 2004.

[21] F.T.T. Phua, Modeling the determinants of multi-firm project success: a grounded exploration of different participant perspectives, Construction Management and Economics, vol. 22, no. 5, pp. 451-459, 2004. 
34 IDENTIFYING CRITICAL SUCCESS FACTORS FOR CONSTRUCTION PARTNERING IN VIETNAM

[22] T.S. Slater, Partnering: agreeing to agree, Journal of Management in Engineering, vol. 14, no. 6, pp. 48-50, 1998.

[23] W. Tang, C.F. Duffield, D.M. Young, Partnering mechanism in construction: an empirical study on the Chinese construction industry, Journal of Construction Engineering and Management, vol. 132, no. 3, pp. 217-229, 2006.

[24] S.R. Toor and S.O. Ogunlana, Critical COMs of success in large-scale construction projects: evidence from Thailand construction industry, International Journal of Project Management, vol. 26, no. 4, pp. 420-430, 2008.

[25] A.T.W Yu, Q. Shen, J. Kelly, and K. Hunter, Investigation of critical success factors in construction project briefing by way of content analysis, Journal of Construction Engineering and Management, vol. 132, no. 11, pp. 1178-1186, 2006.

\section{XÁC ĐỊNH CÁC YẾU TỐ THÀNH CÔNG CHO HỢP TÁC TRONG XÂY DỤ̂NG Ở VIẸTT NAM}

Tóm tắt. Hợp tác đã được áp dụng trong ngành công nghiệp xây dựng Việt Nam trong những năm gần đây vì có nhiều thách thức từ hội nhập toàn cầu và bùng nổ kinh tế. Bài báo này tập trung vào các yếu tố thành công cho hợp tác trong ngành công nghiệp xây dựng Việt Nam. Sử dụng phương pháp trị trung bình, bài báo này xác định được 6 yếu tố quan trọng cho hợp tác trong xây dựng ở Việt Nam gồm: bảo đảm tài chính, quyết tâm của quản lý cấp cao, tin tưởng lẫn nhau giữa các bên, nguồn lực đầy đủ, thông tin liên lạc hiệu quả, và hiểu rõ về quy mô và các mục tiêu. Sử dụng kỹ thuật phân tích nhân tố, bài báo này xác định được 8 thành phần chính cho hợp tác trong xây dựng ở Việt Nam gồm: cống hiến, sẵn sàng, hợp tác, làm việc nhóm, đầy đủ, lãnh đạo, cân bằng, và rõ ràng. Các phát hiện có thể là thông tin hữu ích về triển khai hợp tác trong xây dựng ở Việt Nam và từ đó, tăng cơ hội thành công cho hợp tác.

Từ khóa. xây dựng, yếu tố thành công, hợp tác, Việt Nam.

Ngày nhận bài: 29/09/2017

Ngày chấp nhận đăng: 31/12/2017

C 2017 Trường Đại học Công nghiệp thành phố Hồ Chí Minh 